\title{
Optimisasi Penempatan Posisi Access Point pada Jaringan Wi-Fi Menggunakan Metode Simulated Annealing
}

\author{
Nila Feby Puspitasari*1, Reza Pulungan ${ }^{2}$ \\ ${ }^{1}$ Jurusan Teknik Informatika, STMIK AMIKOM Yogyakarta \\ ${ }^{2}$ Jurusan Ilmu Komputer dan Elektronika, FMIPA, Universitas Gadjah Mada, Yogyakarta \\ E-mail: ${ }^{* 1}$ nilafeby@amikom.ac.id, ${ }^{2}$ pulungan@ugm.ac.id
}

\begin{abstract}
Abstrak
Penempatan access point pada jaringan Wi-Fi yang tepat sangat diperlukan untuk mengoptimalkan kekuatan sinyal yang diterima dari transmitter terhadap receiver. Parameter yang paling mempengaruhi dalam menentukan performa access point adalah nilai kekuatan sinyal, karena nilai inilah yang akan digunakan untuk menentukan coverage area (cakupan sinyal) dari sebuah transmitter (access point).

Pada penelitan ini telah dilakukan pengukuran terhadap kekuatan sinyal access point terhadap penerima di ruang dosen dan lobi gedung 2 lantai 1 STMIK AMIKOM Yogyakarta yang diukur menggunakan aplikasi inSSIDer dan menghasilkan nilai RSSI (Received Signal Strength Indication) dari sebuah transmitter terhadap receiver. Dalam pengukuran juga digunakan propagasi Line Of Sight (LOS) dan propagasi Non Line Of Sight (NLOS). Data yang diperoleh dari hasil pengukuran di lapangan digunakan untuk melakukan pemodelan penempatan access point menggunakan metode simulated anneling. Kekuatan sinyal RSSI yang diterima oleh receiver tidak hanya bergantung pada jarak antara transmitter dan receiver, akan tetapi menunjukkan variasi yang besar terhadap fading dan shadowing pada sebuah lokasi, juga pengaruh interferensi dapat menyebabkan penurunan sinyal (RSSI) yang diterima oleh receiver.

Dari hasil penelitian yang dilakukan, diharapkan dapat menghasilkan pemodelan yang sesuai dan tepat guna dalam melakukan optimisasi penempatan access point pada jaringan WiFi menggunakan metode simulated annealing.
\end{abstract}

Kata Kunci - Wi-Fi, Coverage Area, RSSI, Propagasi, Simulated Annealing

Abstract
Access point placement on Wi-Fi networks is needed to optimize the strength of signal received by receiver from transmitter. The most influential parameter in determining the performance of access point position is signal strength, because this value will be used to determine the coverage area of a transmitter.

In this research, signal strengths of access point to receiver in the faculty room and the lobby floor 1 of building 2 at STMIK AMIKOM Yogyakarta have been measured using inSSIDer application and results in the values of RSSI from transmitter to receiver. Also measured are LOS propagation and NLOS propagation. Data obtained from the field measurements are used to model and analyse the influence of access point placement using simulated annealing. It is found that the RSSI signal strength received by the receiver does not only depend on the distance between the transmitter and receiver, but also shows large variations caused by the fading and shadowing at a location. The interference also causes a decrease in the signal (RSSI) received by the receiver.

The research conducted is expected to generate an appropriate model and analysis for further optimization of access point position on Wi-Fi network using simulated annealing.

Keywords - Wi-Fi, Coverage Area, RSSI, Propagation, Simulated Annealing 


\section{PENDAHULUAN}

Optimisasi penempatan access point merupakan salah satu permasalahan di bidang infrastructure network, dikarenakan untuk menempatkan access point secara optimal pada jaringan Wi-Fi diperlukan pertimbangan dan analisa teoritis sebelum diimplementasikan. Ada cara praktis yang dapat dilakukan untuk menempatkan access point yakni menempatkan access point di tengah-tengah ruangan atau lokasi, namun terkadang hal ini tidak dapat dilakukan karena dalam perencanaan pengembangan jaringan Wi-Fi tidak hanya sekedar memasang infrastruktur perangkat access point, tetapi juga harus memperhatikan beragam faktor antara lain kekuatan daya pancar sinyal access point, desain dan infrastruktur ruangan, sebaran pengguna access point yang berkelompok, terjadinya interferensi gelombang radio, hambatan sinyal seperti frekuensi radio, dan penghalang yang dapat menimbulkan gangguan terhadap penerimaan sinyal dari access point (transmitter) terhadap perangkat penerima (receiver). Posisi access point sangat berpengaruh terhadap area tercover untuk penerima pada sebuah jaringan Wi-Fi. Semakin optimal penempatan posisi access point, semakin optimal juga area tercover untuk penerima.

Oleh karena itu, menempatkan access point dengan cara manual tentunya akan membutuhkan tenaga yang lebih untuk melakukan survey pengukuran di lapangan, waktu yang lama dan biaya yang tidak murah. Untuk itu dibutuhkan penanganan dan mekanisme yang baik dalam meminimalisir tenaga, biaya dan waktu seorang perencana jaringan Wi-Fi dalam menempatkan access point pada tempat yang optimal sehingga cakupan area yang dihasilkan lebih optimal serta dapat menentukan jumlah access point yang ideal untuk suatu lokasi dengan berbagai ukuran yang ada yang dapat ditentukan melalui perhitungan tanpa melakukan survey lapangan yang aktual.

Ketertarikan peneliti untuk melakukan penelitian ini disebabkan karena peneliti bermaksud akan melakukan optimisasi terhadap access point pada jaringan Wi-Fi. Hasil penelitian [1] memperlihatkan cara untuk menentukan coverage area maksimum dengan metode Monte Carlo berdasarkan fungsi jarak dari hasil pengukuran di lapangan. Dari penelitian tersebut dapat disimpulkan bahwa berdasarkan hasil pengukuran dapat diketahui bahwa level daya terima berbanding terbalik dengan jarak antara pemancar (Tx) dan penerima (Rx), semakin jauh jarak antara pemancar (Tx) dan penerima (Rx) maka level daya terima semakin kecil. Penelitian [2] memperlihatkan cara untuk menentukan coverage area maksimum dengan algoritma genetika melalui perhitungan parameter yang dicari untuk menentukan fungsi fitness dari algoritma genetika berdasarkan fungsi jarak dari hasil pengukuran di lapangan. Dari penelitian tersebut dapat disimpulkan bahwa level daya terima berbanding terbalik dengan jarak antara pemancar (Tx) dengan penerima (Rx); semakin jauh jarak antar pemancar (Tx) dan penerima (Rx) maka level daya terima semakin kecil. Hasil penelitian [3] menunjukkan bahwa alokasi fungsi obyektif didasarkan pada rata-rata minimal path lost yang diterima dari seluruh desain area dan maksimum path loss yang diterima kepada penerima. Model yang dijelaskan tersebut dapat digunakan untuk mencari penempatan optimal access point yang mengcover pengguna sebanyak mungkin. Metode yang digunakan untuk memecahkan masalah tersebut adalah Gradient Diskrit. Hasil yang diperoleh menunjukkan bahwa nilai parameter $\psi$ dalam $[0,1]$ memiliki efek pada lokasi access point. Hal ini dapat digunakan untuk menemukan solusi menengah antara dua kasus pada model matematika. Hasil penelitian [4] adalah tentang optimisasi Traveling Salesman Problem (TSP) dengan pendekatan Simulasi Annealing. Dalam penelitian tersebut dibahas salah satu penerapan dari simulasi bersyarat (conditional simulation) yaitu Simulasi Annealing dalam mencari rute terpendek (optimisasi) dari permasalahan Traveling Salesman Problem (TSP). Proses Simulasi Annealing analogis dengan proses pada pendinginan logam cair dimana terdapat proses pertukaran rute-rute perjalanan guna mendapatkan rute perjalanan yang menghasilkan total jarak perjalanan keseluruhan yang minimum dan untuk menjalankan algoritma Simulasi Annealing digunakan bantuan software Matlab. Hasil penelitian [5] adalah tentang kinerja algoritma simulated annealing pada peletakan lokasi (lokalisasi) Wi-Fi menggunakan Google indoor map. Pada penelitian ini, parameter yang digunakan adalah fungsi jarak dan RSS (Received Signal Strength). Metode yang diusulkan diuji menggunakan data home depot dan terbukti lebih akurat 
dibandingkan dengan Google map indoor dalam menemukan sebuah lokasi, metode centroid, KNN (K-Nearest Neighborhood), Density Access Point dan metode kernel murni. Hasil penelitian [6] adalah tentang perbandingan Log Distance Path Loss Model dan Indoor Empirical Propagation Model (IEPM) dalam pengoptimalan letak sistem Wi-Fi di kampus. Dari penelitian tersebut dapat disimpulkan bahwa IEPM dapat digunakan untuk memprediksi panjang sinyal pada area indoor jaringan Wi-Fi, Dengan demikian, coverage area dari access point dapat ditentukan melalui perhitungan, tanpa melakukan survey lapangan yang aktual. Hal ini membantu dalam mengoptimalkan jaringan WI-Fi dan mengurangi biaya implementasi.

Oleh karena itu, sebuah pendekatan alternatif yang diusulkan peneliti adalah membuat pemodelan menggunakan perangkat lunak menggunakan metode optimisasi yang memberikan solusi yang lebih "bagus" tanpa melebihi batasan waktu yang disediakan. Solusi yang "bagus" belum tentu yang paling optimum (global optimum) tetapi sudah dapat diterima oleh user [7], Metode optimisasi yang akan digunakan pada penelitian ini adalah Simulated Annealing yang merupakan metode optimisasi yang mensimulasikan proses annealing pada penempatan posisi access point untuk menghasilkan area tercover optimal dengan menggunakan energi seminimal mungkin.

\section{METODE PENELITIAN}

\subsection{Lokasi Penelitian dan Waktu Penelitian}

Penelitian ini dilaksanakan di lingkungan gedung 2 lantai 1 STMIK AMIKOM Yogyakarta, dimana untuk propagasi LOS dilaksanakan di ruang dosen dan untuk propagasi NLOS dilaksanakan di lobi gedung 2 lantai 1. Sedangkan waktu pelaksanaan adalah pada tanggal 7 Juni 2013 sampai dengan 30 Januari 2014. Denah penelitian memiliki luas $226.80 \mathrm{~m}^{2}$ yang di dalamnya terdapat 20 meja dengan ketinggian $0.75 \mathrm{~m}$, sedangkan tinggi ruas meja $1.2 \mathrm{~m}$. Sedangkan lobi memuat ruangan terbuka dan tangga yang menuju lantai 2.

\subsection{Alat dan Bahan}

\subsubsection{Alat}

a. Access Point

Alat ini berfungsi sebagai transmitter yang memancarkan sinyal gelombang radio

b. Netbook/Handphone

Alat ini berfungsi sebagai receiver yang menerima pancaran sinyal gelombang radio dari sebuah atau beberapa access point.

\subsubsection{Bahan}

a. InSSIDER

Bahan yang digunakan dalam penelitian ini berupa:

InSSIDER berfungsi sebagai software aplikasi gratis yang digunakan untuk scanning jaringan Wi-Fi dengan parameter utama SSID dan dapat melacak kekuatan sinyal dari waktu ke waktu serta menentukan pengaturan keamanan, yang dipasang pada Netbook ASUS Eee PC dengan Sistem Operasi Windows 7.

b. Kabel UTP

Digunakan untuk menghubungkan antara repeater dan access point.

c. Meteran

Meteran digunakan untuk mengukur ketinggian access point yang terpasang dan ketinggian receiver. 


\subsection{Prosedur dan Pengumpulan Data}

\subsubsection{Prosedur}

Prosedur penelitian yang dilakukan oleh peneliti adalah:

1. Menyiapkan alat dan bahan.

2. Melakukan verifikasi perangkat Wi-Fi (Access Point) dengan cara melakukan setting IP addrees receiver dan pastikan IP address satu jaringan dengan IP address access point.

3. Cek koneksi terhadap access point dengan receiver.

4. Menginstal aplikasi InSSIDER berbasis Sistem Operasi Windows 7 dan berbasis Android Gingerbread v2.3 yang digunakan untuk mengukur kekuatan sinyal Wi-Fi.

5. Menjalankan aplikasi InSSIDER untuk melakukan scanning Wi-Fi secara otomatis untuk melihat operasi Access point yang berada di sekitarnya sehingga menghasilkan nilai RSSI (Received Signal Strength Indication).

\subsubsection{Teknik Pengumpulan Data}

1. Melakukan perencanaan penelitian yang membahas mengenai data yang akan diambil pada saat penelitian meliputi denah, tinggi access point, koordinat, jarak, RSSI dan propagasi.

2. Menentukan koordinat posisi Access Point dan posisi receiver pada propagasi LOS (Line Of Sight) dan NLOS (Non Line Of Sight), untuk posisi receiver terdapat 43 titik koordinat pada propagasi LOS, dan posisi receiver terdapat 65 titik koordinat propagasi NLOS.

3. Aplikasi inSSIDER yang telah dijalankan akan melaporkan data terhadap nilai RSSI yang diterima oleh receiver.

4. Pengumpulan data selesai.

\subsection{Analisis dan Pemodelan Sistem}

Pemodelan sistem yang akan dibangun pada penelitian ini adalah menggunakan bahasa pemrograman Java. Pemodelan yang dibuat dalam optimisasi penempatan posisi access point menggunakan ruang 2 (dua) dimensi sedangkan metode yang digunakan adalah simulated annealing. Penghitungan terhadap parameter-parameter yang dicari yaitu menentukan fungsi evaluasi atau fungsi objektif dari simulated annealing yang dihasilkan dari fungsi jarak, penghalang, ketinggian transmitter, pengguna, tipe dan merk access point dari hasil pengukuran di lapangan dan melakukan pengujian terhadap 2 (dua) buah perangkat access point yang diletakkan dalam ruang 2 (dua) dimensi dengan sistem propagasi Line Of Sight (LOS) dan Non Line Of Sight (NLOS).

\subsubsection{Pemodelan Sistem Berdasarkan Kondisi Access Point Sebenarnya}

Pada pemodelan yang berdasarkan posisi access point sebenarnya, pemodelan dikelompokkan berdasarkan propagasinya yaitu Line Of Sight (LOS) dan Non Line Of Sight (NLOS). Pemodelan posisi access point nya adalah:

1. Membagi luas ruangan sesuai dengan jumlah ubin, karena pada saat pengukuran, pengambilan titik sampel berdasarkan ubin yang ada di ruangan tersebut. Sample denah penelitian memiliki luas $226,80 \mathrm{~m}^{2}$. Sedangkan luas ubin adalah 2520 satuan ubin yang didapat dari perolehan panjang ruangan 36 satuan ubin dan lebarnya 70 satuan ubin, dimana 1 ubin panjangnya $30 \mathrm{~cm}$.

2. Menentukan perhitungan koordinat yang diawali dari bagian kiri atas ruang dosen $(0,0)$. Selanjutnya pertambahan nilai koordinat sumbu $X$ adalah ke kanan dan pertambahan koordinat sumbu Y adalah ke bawah.

3. Menentukan ketinggian transmitter yang dibagi kedalam tiga jenis ukuran ketinggian yaitu ketinggian $50 \mathrm{~cm}, 120 \mathrm{~cm}$ dan $230 \mathrm{~cm}$. 
4. Menentukan titik koordinat transmitter ke-1 dengan posisi sebenarnya yang berada pada koordinat $(22,28)$ dan titik koordinat transmitter ke-2 dengan posisi access point berada pada koordinat $(22,3)$.

5. Mengukur besarnya RSSI (Received Signal Strength Indication) dari sesuai bertambahnya jauhnya jarak antara koordinat kedua transmitter dan koordinat receiver dengan bantuan aplikasi inSSIDER dengan propagasi LOS (Line Of Sight) dan NLOS (Non Line Of Sight).

6. Menghitung jarak antara titik koordinat transmitter dengan titik koordinat receiver menggunakan rumus matematis pada persamaan (1), yaitu metode Euclidean:

$$
d=\sqrt{(x 1-x 2)^{2}+(y 1-y 2)^{2}}
$$

7. Menentukan batasan nilai range dimana range adalah batasan sinyal yang menjadi ukuran sebuah area dalam skala yang dinyatakan tercover atau tidak tercover oleh sinyal yang dipancarkan access point (transmitter). Untuk menghitung nilai range diperoleh rumus pada persamaan (2):

$$
\text { Range }=\frac{S}{\text { Skala ruang }}
$$

Dimana Range memiliki satuan pixel, $S$ adalah jarak threshold dan skala ruang $=30 \mathrm{~cm}$, jarak threshold diperoleh dari persamaan rumus (3):

$$
S=\frac{\operatorname{Th} x \operatorname{SMax}}{\operatorname{Pmin}}
$$

Dimana $T h$ adalah threshold level daya $=-30 \mathrm{dBm}$, Smax merupakan jarak maksimal hasil pengukuran (dalam satuan m) dan Pmin adalah daya minimum hasil pengukuran.

Sesuai dengan hasil penelitian, didapatkan data-data sebagai berikut:

a) Pada koordinat access point $(22,28)$ dengan propagasi LOS diperoleh variabel data yang ditunjukkan pada Tabel 1.

Tabel 1. Sample variabel penentuan range propagasi LOS

\begin{tabular}{|l|c|l|}
\hline Th & $:$ & $-30 \mathrm{dBm}$ \\
\hline Smax & $:$ & 9,48 meter \\
\hline Pmin & & \\
Tinggi AP $50 \mathrm{~cm}$ & $:$ & $-61,33 \mathrm{dBM}$ \\
Tinggi AP $120 \mathrm{~cm}$ & $:$ & $-57,47 \mathrm{dBM}$ \\
Tinggi AP 230 cm & $:$ & $-57,95 \mathrm{dBM}$ \\
\hline Skala ruang & $:$ & $30 \mathrm{~cm}$ \\
\hline
\end{tabular}

Misalnya untuk menentukan range pada propagasi LOS dengan tinggi access point adalah $120 \mathrm{~cm}$ diketahui:

$$
\begin{aligned}
& S=\frac{-30 \times 9,48}{-57,47}=4,948 \mathrm{~m}=494,8 \mathrm{~cm} \\
& \text { Range }=\frac{S}{30} \quad=\frac{494,8}{30}=16,49 \text { satuan pixel }
\end{aligned}
$$

b) Pada koordinat access point $(22,28)$ dengan propagasi NLOS diperoleh variabel data yang ditunjukkan pada Tabel 2. 
Tabel 2. Sample variabel penentuan range propagasi NLOS

\begin{tabular}{|l|c|l|}
\hline Th & $:$ & $-30 \mathrm{dBm}$ \\
\hline Smax & $:$ & 13,95 meter \\
\hline Pmin & $:$ & $-68,93 \mathrm{dBM}$ \\
Tinggi AP $50 \mathrm{~cm}$ & $:$ & $-62,34 \mathrm{dBM}$ \\
Tinggi AP $120 \mathrm{~cm}$ & $:$ & $-56,12 \mathrm{dBM}$ \\
Tinggi AP $230 \mathrm{~cm}$ & $:$ & $30 \mathrm{~cm}$ \\
\hline Skala ruang & \\
\hline
\end{tabular}

Perhitungan range pada propagasi NLOS dilakukan dengan cara yang sama, sehingga diperoleh range untuk propagasi NLOS adalah 24,91 satuan pixel.

c) Pada koordinat access point $(22,3)$ dengan propagasi LOS diperoleh variabel data yang ditunjukkan pada Tabel 3.

Tabel 3. Sample variabel penentuan range propagasi LOS

\begin{tabular}{|l|l|l|}
\hline Th & $:$ & $-30 \mathrm{dBm}$ \\
\hline Smax & $:$ & 8,76 meter \\
\hline Pmin & & \\
Tinggi AP $50 \mathrm{~cm}$ & $:$ & $-59,86 \mathrm{dBM}$ \\
Tinggi AP $120 \mathrm{~cm}$ & $:$ & $-60 \mathrm{dBM}$ \\
Tinggi AP $230 \mathrm{~cm}$ & $:$ & $-49,9 \mathrm{dBM}$ \\
\hline Skala ruang & $:$ & $30 \mathrm{~cm}$ \\
\hline
\end{tabular}

Misalnya untuk menentukan range pada propagasi LOS dengan tinggi access point adalah $120 \mathrm{~cm}$ diketahui:

$$
\begin{array}{ll}
S=\frac{-30 \times 8,76}{-60} & =4,38 \mathrm{~m} \quad=438 \mathrm{~cm} \\
\text { Range }=\frac{S}{30} & =14,6 \text { satuan pixel }
\end{array}
$$

d) Pada koordinat access point $(22,3)$ dengan propagasi NLOS diperoleh variabel data yang ditunjukkan pada Tabel 4.

Tabel 4. Sample variabel penentuan range propagasi NLOS

\begin{tabular}{|l|l|l|}
\hline Th & $:$ & $-30 \mathrm{dBm}$ \\
\hline Smax & $:$ & 20,97 meter \\
\hline Pmin & & \\
Tinggi AP $50 \mathrm{~cm}$ & $:$ & $-74,92 \mathrm{dBM}$ \\
Tinggi AP $120 \mathrm{~cm}$ & $:$ & $-69,7 \mathrm{dBM}$ \\
Tinggi AP $230 \mathrm{~cm}$ & $:$ & $-60,61 \mathrm{dBM}$ \\
\hline Skala ruang & $:$ & $30 \mathrm{~cm}$ \\
\hline
\end{tabular}

Untuk perhitungan range pada propagasi NLOS dilakukan dengan cara yang sama, sehingga diperoleh range untuk propagasi NLOS adalah 30,08 satuan pixel.

8. Selanjutnya koordinat-koordinat yang memiliki jarak kurang dari range yang telah ditentukan merupakan daerah yang ter-cover oleh access point koordinat $(22,28)$ dan selanjutnya ditandai dengan warna hijau dan warna biru merupakan daerah yang ter-cover oleh access 
point koordinat $(22,3)$, sedangkan koordinat-koordinat yang memiliki jarak lebih dari range yang telah ditentukan diberi warna merah. Daerah yang berwarna merah akan dioptimalkan sehingga seluruh area dapat tercover oleh access point.

9. Menghitung luas area ter-cover dan dibandingkan dengan luas ruangan yang diamati. Gambar 1 menunjukkan sample area ter-cover kedua access point pada koordinat access point $(22,28)$ dan $(22,3)$ dengan propagasi LOS dan ketinggian access point $120 \mathrm{~cm}$.

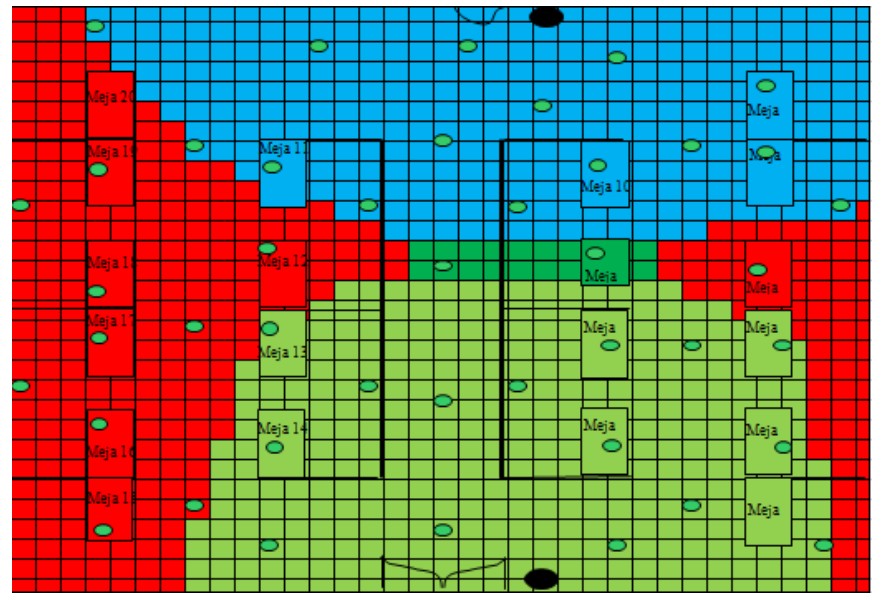

Gambar 1. Sample area ter-cover koordinat access point $(22,28)$ dan $(22,3)$ propagasi LOS dan ketinggian access point $120 \mathrm{~cm}$

Dari Gambar 1 terdapat 2 (dua) titik koordinat yang bersinggungan yang terlihat warna hijau tua dimana merupakan area ter-cover koordinat access point $(22,28)$ dan koordinat access point $(22,23)$. Hasil perhitungan secara matematis, untuk mencari total area ter-cover pada sample area ter-cover seperti yang terlihat pada Gambar 1, perhitungan rumusnya terlihat pada persamaan (4):

$$
\text { Area Tercover }=\sum_{x 2=1}^{n}, \sum_{y 2=1}^{n} \sqrt{(x 1-x 2)^{2}+(y 1-y 2)^{2}} \leq \text { Range }
$$

Dimana $(\mathrm{x} 1, \mathrm{y} 1)$ adalah koordinat posisi access point dan $(\mathrm{x} 2, \mathrm{y} 2)$ adalah posisi koordinat receiver.

10. Menghitung area tercover masing-masing access point dengan koordinat $(22,28)$ dan koordinat $(22,3)$ berdasarkan rumus pada persamaan (4), maka didapatkan area tercover sebesar: Pada koordinat access point $(22,28)$ diperoleh area tercover sebesar 195.3395 skala koordinat dan area tercover koordinat access point $(22,3)$ diperoleh sebesar 149.5624 skala koordinat.

11. Menentukan area tercover irisan (intersection) antara kedua access point pada koordinat $(22,28)$ dan koordinat $(22,3)$ yang terletak pada koordinat $(25,13)$ dan koordinat $(18,13)$ dengan rumus pada persamaan (5):

$$
\begin{aligned}
& =\sum_{x 2=1}^{A P 1}, \sum_{y 2=1}^{A P 2} \sqrt{(A P 1 x 1-x 2)^{2}+(A P 1 y 1-y 2)^{2}} \\
& \leq \text { Range \&\& } \sum_{x 2=1}^{n} \sum_{y 2=1}^{n} \sqrt{(A P 2 x 1-x 2)^{2}+(A P 2 y 1-y 2)^{2}} \leq \text { Range }
\end{aligned}
$$

Maka diperoleh area tercover irisan kedua access point sebesar 51.9732 skala koordinat. 
12. Menentukan persentase coverage area gabungan antara kedua access point pada koordinat $(22,28)$ dan koordinat $(22,3)$ menggunakan rumus pada persamaan $(6)$ :

$\%$ Coverage Area $=\frac{(\text { Area Tercover AP1 }+ \text { AP2 })-\text { Irisan Area Tercover }}{\text { Total Area }} \times 100 \%$

Maka didapat persentase coverage area sebesar:

$\%$ Coverage Area $=\frac{(195.3395+149.5624)-51.9732}{2520} \times 100 \%$

$\%$ Coverage Area $=11.62 \%$

Dari hasil pemrograman simulasi diperoleh persentase coverage area gabungan kedua access point diperoleh nilai sebesar $11.51 \%$. Dari hasil tersebut dapat dihitung persentase error dengan menggunakan persamaan (7):

$$
\% \text { Error }=\frac{\text { Perhitungan Teori }- \text { Perhitungan Simulasi }}{\text { Perhitungan Teori }} \times 100 \%
$$

Maka diperoleh persentase error sebesar:

$$
\begin{aligned}
& \% \text { Error }=\frac{11.62-11.51}{11.62} \times 100 \% \\
& \% \text { Error }=0.94 \%
\end{aligned}
$$

\subsubsection{Pemodelan Sistem Berdasarkan Metode Simulated Annealing}

Pada pemodelan menggunakan Simulated Annealing, akan dikembangkan sebuah model implementasi metode simulated annealing untuk penempatan 2 (dua) posisi access point menggunakan interferensi. Ada beberapa hal yang harus dirancang dalam menerapkan metode simulated annealing yaitu fungsi objectif (cost function), mekanisme inisialisasi solusi awal dan pembuatan solusi baru, skema pendinginan atau (cooling schedule) dan penetapan baasan terhadap output yang dikehendaki. Tiap hal tersebut akan diuraikan pada bagian-bagian berikut ini:

1. Fungsi Objektif

Fungsi objektif yang dicari adalah nilai area tercovernya paling besar berdasarkan atas nilai jarak antara transmitter dan receiver diantara sejumlah posisi access point yang telah diinisialisasi secara acak. Pada perhitungan nilai objektif, setelah diperoleh solusi sementara, dilakukan perhitungan jarak baru antara transmitter dan receiver, kemudian diperoleh range baru, selanjutnya dihitung nilai RSSI baru dari receiver, dan hasil akhir dilakukan perhitungan nilai area tercover. Untuk menghitung jarak baru menggunakan rumus pada persamaan (7) yang diturunkan dari rumus pada persamaan (1), dan selanjutnya akan dihitung nilai RSSI baru menggunakan rumus persamaan (7).

$$
\operatorname{NewRSS}_{(i)}=\frac{\text { Th }_{i}}{\text { First Range }_{(i)}} \times \text { Newdistance }_{(i)}
$$

Dimana $T h_{(i)}$ adalah Threshold power $=-30 \mathrm{dBm}$, First Range $_{(i)}=$ Range $_{(i)}$ menggunakan rumus pada persamaan (7) dan Newdistance $_{(i)}=d_{(i)}$ menggunakan rumus pada persamaan (8):

$$
\operatorname{Range}_{(i)}=\frac{-30 \mathrm{dBm} x \operatorname{Smax}_{(i)}}{\operatorname{Pmin}_{(i)}}
$$




$$
\begin{aligned}
& d_{(i)}=\sqrt{(x 1-x 2)_{(i)}^{2}+(y 1-y 2)_{(i)}^{2}} \\
& \text { Area Tercover }_{(i)} \\
& =\sum_{x 2_{(i)}=1}^{n} \sum_{y 2_{(i)}=1}^{n} \sqrt{(x 1-x 2)_{(i)}^{2}+(y 1-y 2)_{(i)}^{2}} \leq \text { Range }_{(i)}
\end{aligned}
$$

2. Inisialisasi Awal dan Mekanisme Pembuatan Solusi Baru

Pada penelitian ini, solusi awal untuk formasi penempatan access point diinisialisasi secara acak dengan cara membagi access point secara acak kedalam koordinat-koordinat yang terdapat pada area penelitian, koordinat ini didapat berdasarkan jumlah ubin dalam ruang penelitian dimana koordinat panjang (koordinat $\mathrm{x}$ ) dan koordinat lebar (koordinat $\mathrm{y}$ ) dan setiap access point akan mengalokasikan kepada receiver nilai RSSI yang baru pada koordinat tertentu yang telah ditetapkan sehingga diperoleh perubahan jarak antara acess point dan receiver, kemudian akan dihitung nilai range yang baru untuk menghasilkan nilai area tercover optimal. Mekanisme yang digunakan untuk membangkitkan solusi baru adalah pilih access point secara acak terhadap koordinat sebagai tempat posisi access point yang baru, yang bukan merupakan koordinat yang ditempati sebelumnya, kemudian setiap access point akan mengalokasikan kepada receiver dengan nilai RSSI yang baru sesuai dengan perubahan jarak.

3. Skema Pendinginan

Sebelum proses annealing dilakukan, harus ditetapkan terlebih dahulu skema pendinginan yang akan digunakan. Pada prinsipnya, semakin lambat proses annealing berlangsung, maka semakin besar peluangnya untuk menghasilkan solusi yang lebih baik, karena jumlah solusi yang dapat dievaluasi semakin banyak atau ruang pencarian yang dapat dijelajahi semakin luas. Ada tiga cara yang ditempuh untuk memperlambat laju proses annealing, yaitu : dengan memperbesar nilai temperatur awal, atau memperkecil temperatur akhir, memperbesar faktor penurunan temperatur dan memperbesar jumlah iterasi dalam tiap nilai dalam tiap nilai temperatur. Setelah melakukan serangkaian percobaan terhadap berbagai kombinasi nilai parameter annealing, dengan mempertimbangkan kualitas solusi dan waktu komputasi yang dibutuhkan, maka dipilih cooling schedule dimana temperatur awal = 1000; temperatur akhir $=1$; faktor penurunan temperatur $=0,995$; dan maksimum jumlah iterasi $=1000$;

4. Proses Iterasi

Proses iterasi dilakukan untuk mencari nilai nilai area tercover paling optimal dimana proses iterasinya dilakukan dengan metode pencarian acak tanpa nilai target, pencarian dilakukan hingga diperoleh nilai tertinggi, karena tanpa nilai target maka solusi saat ini selalu dibandingkan dengan nilai sebelumnya untuk menunjukkan tingkat akurasi dari nilai solusi.

Berdasarkan uraian di atas, akan dikembangkan sebuah pemodelan menggunakan metode simulated annealing pada penempatan posisi access point seperti ditunjukkan pada Gambar 2. 


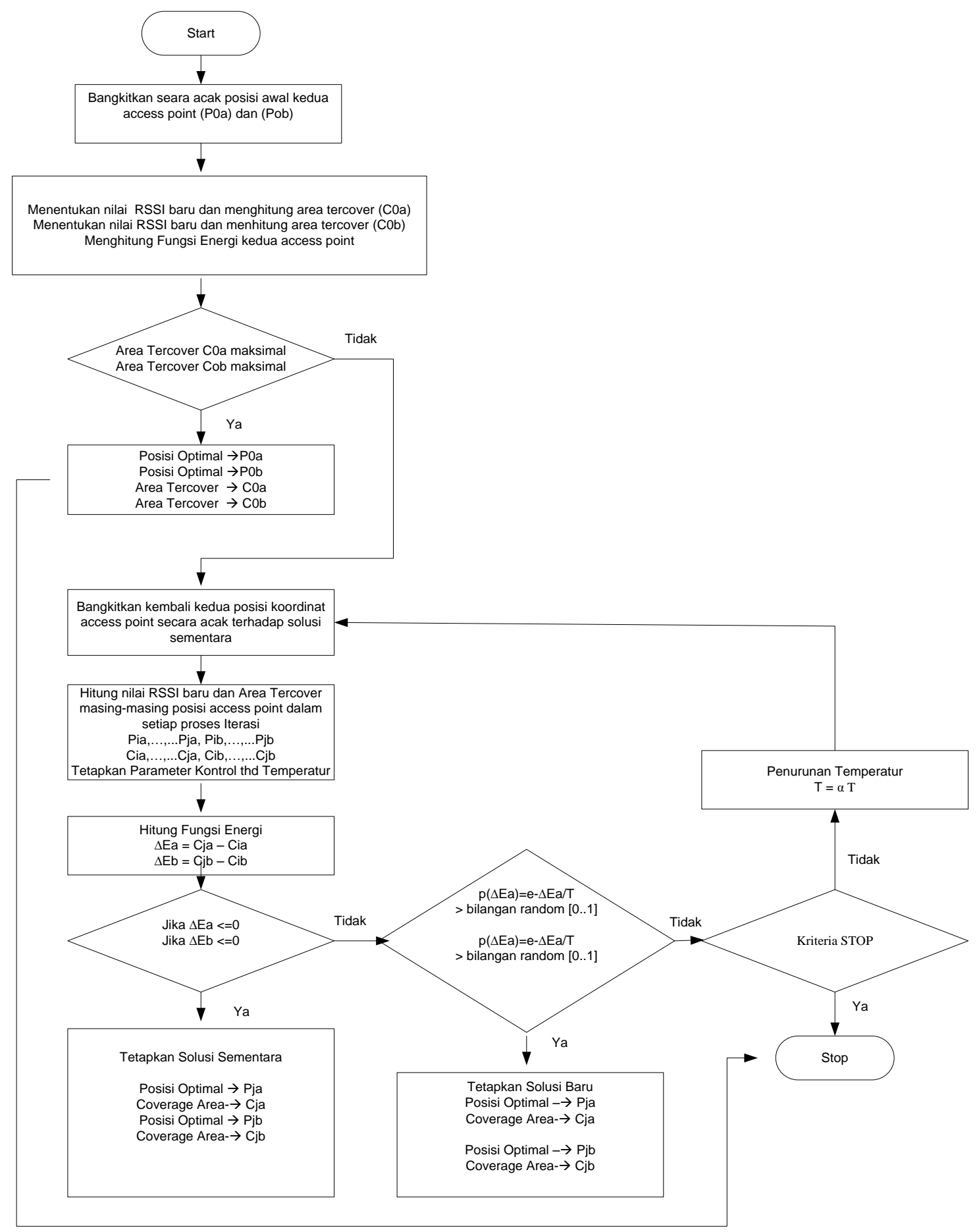

Gambar 2. Flowchart pemodelan penempatan posisi Access Point dengan interferensi menggunakan Simulated Annealing 


\section{HASIL DAN PEMBAHASAN}

Pada bagian ini akan dijelaskan mengenai serangkaian pengujian dan evaluasi terhadap metode yang digunakan. Pengujian dilakukan untuk mengetahui kinerja terhadap metode yang dihasilkan dari proses implementasi. Evaluasi dilakukan dengan cara menganalisis hasil pengujian tersebut, untuk kemudian dilakukan kesimpulan dan saran bagi perangkat lunak selanjutnya. Data yang digunakan dalam penelitian ini ada 648 data yang dikelompokkan berdasarkan koordinat access point dengan koordinat $(22,28)$ dan koordinat $(22,3)$ dan 3 (tiga) jenis ukuran tinggi access point yaitu $50 \mathrm{~cm}, 12 \mathrm{~cm}$ dan 230 serta 2 (dua) jenis propagasi yaitu propagasi LOS (Line Of Sight) yang terdiri dari 43 data dan NLOS (Non Line Of Sight) yang terdiri dari 65 data.

Ada beberapa pengujian yang dilakukan dalam penelitian ini yaitu:

1. Pengujian transmitter berdasarkan parameter merk, tinggi dan propagasinya terhadap receiver berdasarkan parameter koordinat, jarak, dan RSSI.

2. Membandingkan hasil pengujian berdasarkan parameter posisi access point sebenarnya dengan posisi access point hasil optimisasi menggunakan interferensi dengan metode simulated annealing.

3. Melakukan analisis data hasil optimisasi terhadap pengukuran awal.

\subsection{Penentuan Parameter Terhadap Transmitter}

Pengujian yang dilakukan terhadap transmitter adalah:

1. Menentukan perangkat access point dengan Merk TP-Link, Tipe TL-WA701ND.

2. Mengatur konfigurasi interferensi dengan menentukan merk perangkat dan nama access point.

3. Menentukan parameter tinggi transmitter dan dikelompokkan menjadi 3 (tiga) jenis ketinggian yaitu ketinggian $50 \mathrm{~cm}, 120 \mathrm{~cm}$ dan $230 \mathrm{~cm}$.

4. Menentukan posisi awal transmitter pada koordinat $(22,28)$.

5. Menentukan jenis propagasi yaitu LOS (Line Of Sight) dan NLOS (Non Line Of Sight).

6. Setelah mengatur konfigurasi perangkat access point, kemudian akan tampil data receiver yang merupakan data hasil pengukuran berdasarkan posisi access point sebenarnya.

7. Penentuan denah sebagai sample penelitian

8. Memilih denah yang telah di package dalam bentuk file.PNG dengan resolusi gambar $420 \mathrm{x}$ 816 pixel.

9. Melakukan optimisasi dengan Simulated Annealing

Pengujian yang dilakukan oleh peneliti dalam rangka optimisasi penempatan posisi access point menggunakan metode simulated annealing dilakukan sebanyak 3 (tiga) jenis sample pengujian yaitu pada ketinggian access point $50 \mathrm{~cm}, 120 \mathrm{~cm}$ dan $230 \mathrm{~cm}$ dengan propagasi LOS dan NLOS.

\subsection{Hasil Simulasi dan Analisa}

\subsubsection{Analisa Pengaruh Perubahan Tinggi Access Point terhadap Nilai RSSI}

Perubahan tinggi access point memberikan pengaruh yang besar terhadap nilai RSSI yang diterima oleh receiver. Dapat dilihat pada data hasil uji coba sebelumnya bahwa pada propagasi LOS, semakin tinggi access point yang terpasang, presentase coverage area yang dihasilkan lebih optimal. Sedangkan pada propagasi NLOS semakin tinggi access point yang terpasang presentase coverage area yang dihasilkan juga lebih optimal. 


\subsubsection{Analisa Kekuatan Hasil Optimisasi}

Setelah dilakukan ujicoba optimisasi menggunakan simulated annealing dengan membangkitkan secara acak koordinat kedua access point (random) sebanyak masing-masing 3 kali berdasarkan 3 (tiga) sample ujicoba yaitu jenis ukuran ketinggian dan jenis propagasi, maka diperoleh analisa data sebagai berikut:

1. Pada jenis ukuran ketinggian access point $50 \mathrm{~cm}$ dengan propagasi LOS, diperoleh persentase area terbaik sebesar $98.42 \%$ yaitu pada titik koordinat $(6,18)$ untuk access point pertama dan titik koordinat $(1,12)$ untuk access point kedua. Sedangkan pada jenis ukuran ketinggian access point $50 \mathrm{~cm}$ dengan propagasi NLOS, diperoleh persentase area terbaik sebesar $78.09 \%$ yaitu pada titik koordinat $(12,60)$ untuk access point pertama dan titik koordinat $(8,16)$ untuk access point kedua. Adapun sample grafik iterasi coverage area untuk propagasi LOS pada hasil pemodelannya dapat ditampilkan pada Gambar 3.

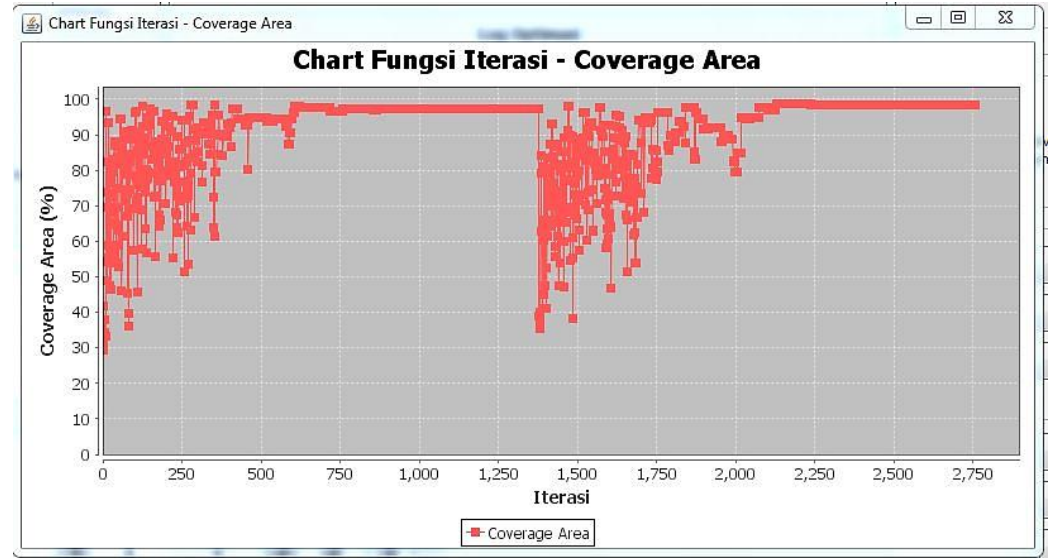

Gambar 3. Sample Grafik Iterasi Coverage Area

Hasil Pemodelan Tinggi AP $50 \mathrm{~cm}$ Propagasi LOS

2. Pada jenis ukuran ketinggian access point $120 \mathrm{~cm}$ dengan propagasi LOS, diperoleh persentase area terbaik sebesar $98.66 \%$ yaitu pada titik koordinat $(7,13)$ untuk access point pertama dan titik koordinat $(35,5)$ untuk access point. Sedangkan pada jenis ukuran ketinggian access point $120 \mathrm{~cm}$ dengan propagasi NLOS, diperoleh persentase area terbaik sebesar $94.89 \%$ yaitu pada titik koordinat $(1,3)$ untuk access point pertama dan titik koordinat $(7,35)$ untuk access point kedua. Adapun sample grafik iterasi coverage area untuk propagasi LOS pada hasil pemodelannya dapat ditampilkan pada Gambar 4.

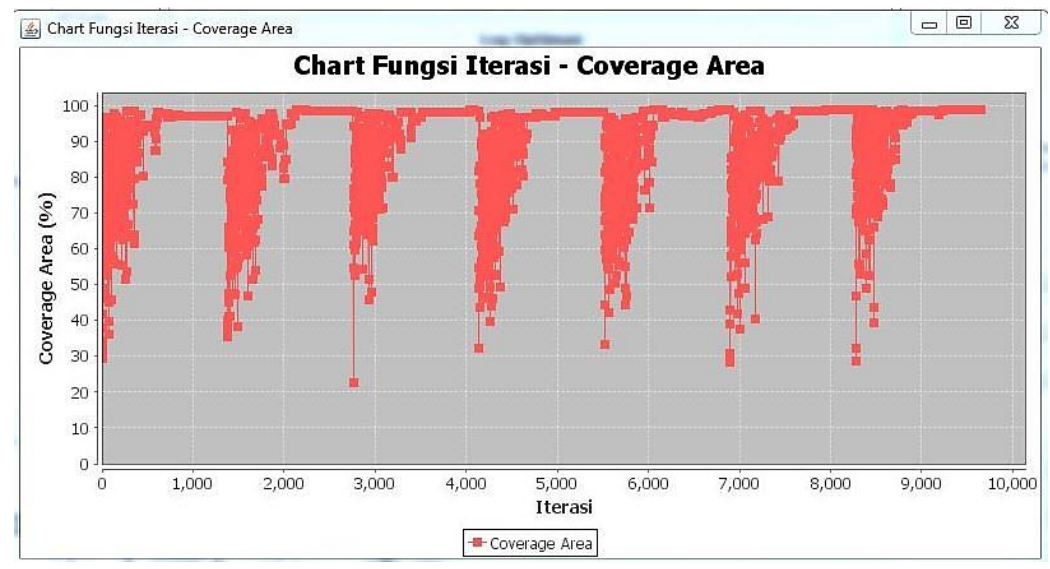

Gambar 4. Sample grafik Iterasi Coverage Area

Hasil Pemodelan tinggi AP $120 \mathrm{~cm}$ propagasi LOS 
3. Pada jenis ukuran ketinggian access point $230 \mathrm{~cm}$ dengan propagasi LOS, diperoleh persentase area terbaik sebesar $98.66 \%$ yaitu pada titik koordinat $(1,16)$ untuk access point pertama dan titik koordinat $(16,8)$ untuk access point kedua dan alternative keduanya adalah titik koordinat $(1,1)$ untuk access point pertama dan titik koordinat $(20,6)$ untuk access point kedua. Sedangkan pada jenis ukuran ketinggian access point $230 \mathrm{~cm}$ dengan propagasi NLOS, diperoleh persentase area terbaik sebesar $97.83 \%$ yaitu pada titik koordinat $(29,20)$ untuk access point pertama dan titik koordinat $(1,19)$ untuk access point kedua. Adapun sample grafik iterasi coverage area untuk propagasi LOS pada hasil pemodelannya dapat ditampilkan pada Gambar 5.

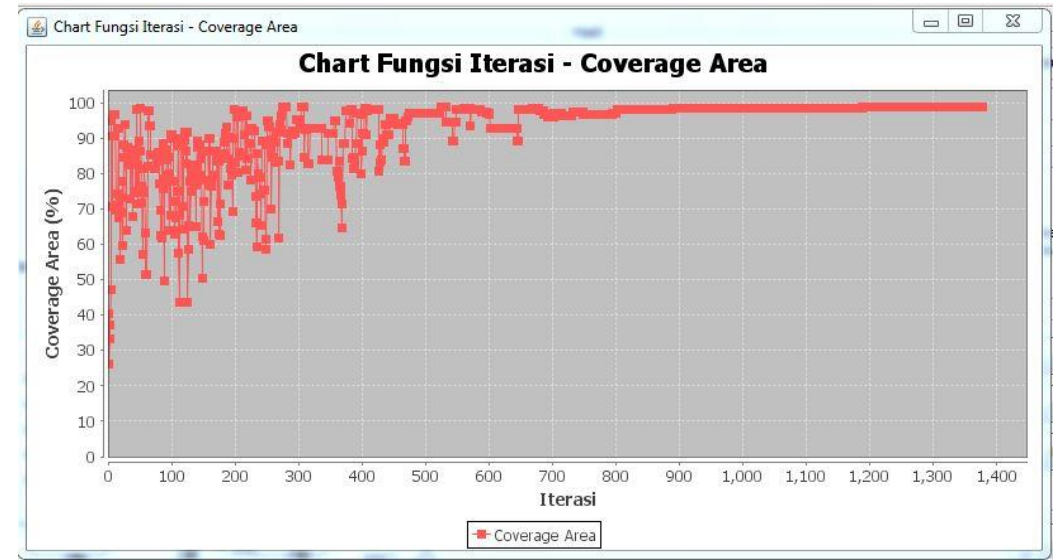

Gambar 5. Grafik Iterasi Coverage Area

Hasil Pemodelan tinggi AP $230 \mathrm{~cm}$ propagasi LOS

\subsubsection{Analisa Perbandingan Kekuatan Sinyal Hasil Optimisasi terhadap Kondisi Awal}

Terjadi peningkatan kekuatan sinyal yang cukup signifikan terhadap penempatan posisi access point dengan kondisi awal dibandingkan hasil kekuatan sinyal setelah dibuat pemodelan menggunakan metode simulated annealing. Sebagai contoh pada kondisi awal ketinggian access point $120 \mathrm{~cm}$ dengan propagasi LOS memperoleh persentase coverage area sebesar $11.51 \%$. Setelah dilakukan optimisasi menggunakan simulated annealing persentase coverage areanya sebesar $98.66 \%$. Dengan demikian kenaikan persentase coverage area sebesar $87.15 \%$.

\section{KESIMPULAN}

Berdasarkan uraian hasil pembahasan sebelumnya dapat disimpulkan bahwa:

1. Metode yang dikembangkan dalam penelitian ini memberikan hasil optimisasi yang lebih baik dibandingkan dengan perencanaan awal.

2. Berdasarkan hasil pengujian dengan pemodelan sistem menggunakan metode simulated annealing dengan nilai threshold level daya sebesar -30 dBM, menunjukkan bahwa:

a. Penempatan tinggi kedua access point pada ketinggian $120 \mathrm{~cm}$ dan ketinggian $230 \mathrm{~cm}$ pada propagasi LOS untuk lingkungan ruang dosen gedung 2 lantai 1 STMIK AMIKOM Yogyakarta menghasilkan presentase coverage area terbaik yang sama yaitu sebesar $98.66 \%$. Adapun pada ketinggian $120 \mathrm{~cm}$ titik koordinatnya adalah $(7,13)$ untuk access point pertama dan titik koordinat $(35,5)$ untuk access point kedua, sedangkan pada ketinggian $230 \mathrm{~cm}$ titik koordinatnya adalah $(1,16)$ untuk access point pertama dan titik koordinat $(16,8)$ untuk access point kedua serta alternatif pilihan titik koordinat $(1,1)$ untuk access point pertama dan titik koordinat $(20,6)$ untuk access point kedua, adapun hasil yang diperoleh lebih optimal dibandingkan dengan penempatan tinggi access point 
pada ketinggian $50 \mathrm{~cm}$ yang memperoleh presentasi coverage area sebesar 98,42\% pada titik koordinat $(6,18)$ untuk koordinat access point pertama dan titik koordinat $(1,12)$ untuk access point kedua.

b. Pada propagasi NLOS untuk lingkungan ruang dosen gedung 2 lantai 1 STMIK AMIKOM Yogyakarta penempatan access point pada ketinggian $230 \mathrm{~cm}$ memiliki presentase coverage area sebesar $97.83 \%$ yaitu pada titik koordinat $(29,20)$ untuk access point pertama dan titik koordinat $(1,19)$ untuk access point kedua, lebih baik dibandingkan tinggi aceess point pada ketinggian $120 \mathrm{~cm}$ yang memperoleh presentase coverage area sebesar $94,89 \%$ pada titik koordinat $(1,3)$ untuk koordinat access point pertama dan titik koordinat $(7,35)$ untuk access point kedua, dan ketinggian access point $50 \mathrm{~cm}$ yang memperoleh presentase coverage area $78.09 \%$ pada titik koordinat $(12,60)$ untuk koordinat access point pertama dan titik koordinat $(8,16)$ untuk access point kedua.

\section{SARAN}

1. Semakin banyaknya pengujian yang dilakukan, maka akan mendapatkan kemungkinan hasil yang lebih baik terhadap hasil optimisasi sebelumnya.

2. Ruang lingkup penelitian diperluas menjadi skala yang lebih besar untuk melihat kemampuan metode yang digunakan dalam penelitian.

\section{DAFTAR PUSTAKA}

[1] Sari, I. P., Santoso, T., Siswandari, N. A., 2010. Optimisasi Penataan Sistem Wi-Fi di PENSITS dengan Menggunakan Metode Monte Carlo, Seminar Proyek Akhir Jurusan Telekomunikasi, Politeknik Elektronika Negeri Surabaya - ITS, Surabaya.

[2] Kartika, K. P., Santoso, T. B., Siswandari, N. A., 2010, Optimisasi Penataan Sistem Wi-Fi di PENS-ITS dengan Menggunakan Metode Algoritma Genetika, Seminar Proyek Akhir Jurusan Telekomunikasi, Politeknik Elektronika Negeri Surabaya - ITS, Surabaya.

[3] Kouhbor, S., Ugon, J., Kruger, A., Rubinov, A., 2005, Optimal Placement of Access Point in WLAN Based on a New Algorithm, International Conference on Mobile Business, ICMB 2005, Sydney, Australia, 11-13 Juli 2005.

[4] Rizal, J., 2007, Optimisasi Pada Traveling Salesman Problem (TSP) dengan Pendekatan Simulasi Annealing, Jurnal Gradien, Vol 3, No 2, Hal 286-290.

[5] Zheng, X., Bao, G., Fu, R., Pahlavan, K., 2012, The performance of Simulated Annealing Algorithms for Wi-Fi Localization using Google Indoor Map, Prosiding IEEE Vehicular Technology Conference, Quebec City, Canada, 3-6 September 2012.

[6] Sandeep, A. R., Shreyas, Y., Seth, S., Agarwal, R., Sadashivappa, G., 2008. Wireless Network Visualization and Indoor Empirical Propagation Model for a Campus WI-FI Network, World Academy of Science, Engineering and Technology, Vol 42, Hal 730-734.

[7] Suyanto, 2010, Algoritma Optimisasi Deterministik atau Probabilistik, Graha Ilmu Yogyakarta. 